\section{Improving Exam Performance in Introductory Biology through the Use of Preclass Reading Guides}

\author{
Rebekah Lieu, ${ }^{\dagger}$ Ashley Wong, ${ }^{\dagger}$ Anahita Asefirad, ${ }^{\dagger}$ and Justin F. Shaffer*
}

Department of Developmental and Cell Biology, University of California, Irvine, Irvine, CA 92697

\begin{abstract}
High-structure courses or flipped courses require students to obtain course content before class so that class time can be used for active-learning exercises. While textbooks are used ubiquitously in college biology courses for content dissemination, studies have shown that students frequently do not read their textbooks. To address this issue, we created preclass reading guides that provided students with a way to actively engage with the required reading for each day of class. To determine whether reading guide completion before class is associated with increased performance, we surveyed students about their use of reading guides in two sections of a large-enrollment (400+ students) introductory biology course and used multiple linear regression models to identify significant correlations. The results indicated that greater than $80 \%$ of students completed the reading guides before class and that full completion of the reading guides before class was significantly positively correlated with exam performance. Reading guides in most cases were used similarly between different student groups (based on gender, ethnicity, and aptitude). These results suggest that optional preclass reading guides may help students stay on track to acquire course content in introductory biology and thus result in improved exam performance.
\end{abstract}

\section{INTRODUCTION}

Recent calls for reforming undergraduate biology education have recommended increasing student engagement and the teaching of scientific literacy skills (American Association for the Advancement of Science, 2011; President's Council of Advisors on Science and Technology, 2012). For class time to be devoted to active learning or delving deeper into the scientific literature, course content needs to be delivered other than during the class meeting time. One way to do this is to hold students responsible for learning the course content before class - this is the basis of "flipped" courses (in which students acquire content before class and then perform active-learning exercises in class) or high-structure courses (in which students acquire content before class and then complete graded preclass assignments, participate in active learning in class, and complete graded weekly review assignments) (Freeman et al., 2011; Eddy and Hogan, 2014; O'Flaherty and Phillips, 2015; Shaffer, 2016). By having students acquire content before class, the course instructor can "hit the ground running" and use active learning to formatively test students on what they have learned, address misconceptions, investigate scientific and ethical issues, and practice scientific literacy skills (Bonwell and Eison, 1991; Allen and Tanner, 2005).

Students can acquire content before class in several ways, although two may predominate in many college courses: watching videos or reading the textbook. While watching videos may be a useful way for students to acquire content, instructors may not have the time to create them nor may they be able to find suitable ones for students to watch (Milman, 2012; Jensen et al., 2015; O'Flaherty and Phillips, 2015). However, it is very common for college biology courses to require students to purchase a textbook for class. Ranging in length, topics, the amount of detail, and the level (majors
Jennifer Momsen, Monitoring Editor Submitted December 14, 2016; Revised April 25, 2017; Accepted May 9, 2017

CBE Life Sci Educ September 1, 2017 16:ar46 DOI:10.1187/cbe.16-11-0320

'These authors contributed equally to this work. Conflict of interest statement: J.F.S. has served as a reviewer and content author for Mastering Biology, which was used in the courses assessed in this study. No promotion of Mastering Biology to the exclusion of other similar products should be construed.

*Address correspondence to: Justin F. Shaffer (j.shaffer(auci.edu)

(c) 2017 R. Lieu, A. Wong, A. Asefirad, and J. F. Shaffer. CBE-Life Sciences Education @ 2017 The American Society for Cell Biology. This article is distributed by The American Society for Cell Biology under license from the author(s). It is available to the public under an Attribution-Noncommercial-Share Alike 3.0 Unported Creative Commons License (http://creativecommons.org/ licenses/by-nc-sa/3.0).

"ASCB®" and "The American Society for Cell Biology $\circledast "$ are registered trademarks of The American Society for Cell Biology. 
vs. nonmajors), textbooks can be a useful way for students to learn course content before coming to class. However, many studies have shown that students across a wide variety of college courses do not regularly read their textbooks. Sikorski et al. (2002) surveyed psychology students at two universities and found that, of students who purchased the course textbook, $80 \%$ read less than 3 hours per week and 95\% valued attending lecture and studying course notes more than textbook reading. Clump et al. (2004) found that only $27 \%$ of psychology students regularly read the assigned reading before each day of class, but that number increased to $70 \%$ before an exam. Podolefsky and Finkelstein (2006) found that, while 97\% of physics students purchased the course textbook, only $41 \%$ of students regularly read their textbooks before class, 60\% read after class instead of before, and there was little correlation between reading habits and course performance. Berry et al. (2011) found that, while students in finance courses report that they know it is important to read their textbooks and that it will likely impact their grade, only $8 \%$ of students spent $>3$ hours a week reading their textbooks. These studies and others paint a somewhat grim picture that college students may not be preparing for class by reading their textbooks, even when readings are explicitly assigned by instructors.

Why is it that students do not read their textbooks? With regard to biology and science textbooks, many possible reasons exist. First, students may not be familiar with the style of writing that is found in science textbooks (Hodges, 2015). Science writing is denser than narrative writing and other styles; often assumes the reader has specific prior knowledge on which to scaffold new concepts; and uses figures, graphs, and equations that may prove to challenging for students (Snow, 2010; van den Broek, 2010). Additionally, science textbooks introduce students to countless new vocabulary words that are often unusual and linked to languages (e.g., Latin and Greek) that students are not familiar with (Groves, 1995; Fang, 2006; Shanahan, 2012). Because of the nature of science writing, students may feel overwhelmed and develop a seemingly insurmountable cognitive load that they cannot overcome, which then results in them failing to read (van den Broek, 2010; Hodges, 2015). Second, students may not understand the purpose of reading their textbooks. While students may think that the goals of textbook reading are to immediately prepare for exams or for long-term accumulation of knowledge to prepare for careers (Elshout-Mohr and van Daalen-Kapteijns, 2002), instructors may have other goals that students do not realize. Instructors may wish for students to critically evaluate the text, analyze data from figures, or make connections to topics covered in past courses. Additionally, instructors may simply want students to read before class in order to be better prepared for in-class lessons (Hodges, 2015). This potential disconnect in purpose may lead to students not seeing the value in reading, and thus they simply will not read. Finally, students may not be motivated to read in the first place. Students may not be intrinsically motivated to read because they lack interest in the subject matter or they do not experience personal satisfaction when reading. Extrinsic motivations to read (course points, reading quizzes, etc.) may also not exist in a given course (Hodges, 2015), and thus students fail to see the immediate rewards for reading. No matter the reason why students do not read, in the case of a flipped or high-structure course, wherein preclass preparation is critical for success, not reading before class may be a recipe for disaster.

To address these issues, several attempts have been made to design curricular additions to encourage students to read textbooks. Solomon (1979) developed and used the "two-point system" in a psychology course to reward students who read the assigned reading while not penalizing those who did not. To receive two extra points on an exam, students had to submit a written assignment that related topics from the assigned preclass textbook reading to what they were going to cover in class that day. Using this method, $85 \%$ of students read the assigned readings before class, but there was no effect on final exam scores. In an introductory biology course, Armbruster and colleagues (2009) developed the "daily dozen," a set of questions associated with each lecture that was intended to help students read their textbooks before class. In two social work courses, students reported favorable outcomes from using preclass study guides that were designed to encourage students to read their textbooks before class (Vandsburger and Duncan-Daston, 2011). Greater than $95 \%$ of computer science students reported that optional preclass "exploratory homeworks," which were developed to guide students through the preclass reading and coding assignments, were either sometimes or always helpful toward understanding lecture and lab materials (Esper et al., 2012). By assigning preclass reading quizzes in an introductory physics courses and an introductory physiology course that directed students to specific textbook passages and figures, Heiner et al. (2014) found that $80 \%$ of students regularly read the assigned reading before class and that their preclass quiz scores were positively correlated with exam performance. Common themes from many of these studies include that students are given some sort of guidance on what to read before class, and that there was some reward for completing the assigned readings.

In this study, we developed and assessed custom reading guides for a large-enrollment introductory biology course. The reading guides required students to actively engage with their textbooks while reading by defining terms, explaining concepts, making tables, drawing figures, and answering questions. We hypothesized that full completion of reading guides before each class would help students prepare on a daily basis and would thus be positively correlated with increased examination performance. We found that there was a strong significant positive correlation between reading guide completion and exam performance. We also report on how students used the reading guides and offer recommendations for implementing them in other college science courses.

\section{METHODS}

\section{Course and Student Description}

The course that was studied was a large-enrollment (400+ students) introductory biology course taught on the quarter system (10 weeks) at a large doctoral-granting (R1) institution in the western United States. The course is considered to be the first half in a typical two-course introductory biology sequence and covers foundational concepts in cell biology, molecular biology, and genetics. The entire course enrollment met for three 50-minute lessons per week in a large, fixed-seating lecture hall. Students also attended one 50-minute discussion section per week taught by trained graduate assistants. The course was taught with high structure (Freeman et al., 2011; Eddy and 
Hogan, 2014; Shaffer, 2016), as students were required to read the course textbook and complete daily online assignments via Mastering Biology (Pearson, New York, NY) before class; participate in active-learning exercises and activities, including clicker questions (iClicker software, version 6.3, iClicker, Indianapolis, IN), group work, and discussions in class; and complete weekly review quizzes (Mastering Biology) at the end of each week of class. There were four multiple-choice exams totaling $80 \%$ of the course grade: three midterm exams $(15 \%$ each of the course grade) and a cumulative final exam (35\% of the course grade; approximately half of the final exam covered new material and half was purely cumulative). Greater than $60 \%$ of each exam was composed of Bloom's (Bloom et al., 1956) level-three (application) or higher questions (based on Bloom's levels assigned by the course instructor [J.F.S.]), and no exam questions were identical to questions found in the reading guides. All exams and reading guides are provided in the Supplemental Material. A custom edition of Campbell Biology, 10th ed. (Reece et al., 2014), was used for the course. A single instructor (J.F.S.) taught the two sections (A and B) of the course in Fall 2015 that are included in this analysis.

The course is taught in the Fall quarter, and the students who enroll in this course are primarily freshman biological sciences majors in the first quarter of their college careers. There were 877 students enrolled in the two sections in Fall 2015, and 790 (90\%) provided gender, ethnicity, and Scholastic Aptitude Test (SAT) score data and thus were included in this study (Table 1). Approximately $70 \%$ of the students were female, $42 \%$ of the students were underrepresented minorities (AfricanAmerican, Hispanic/Latin@, or Native American), and 58\% of the students were biological sciences majors.

\section{Reading Guide Structure}

Custom reading guides were created in Microsoft Word 2011 (Microsoft, Redmond, WA) for each lesson (one per day of

\begin{tabular}{lc} 
TABLE 1. Demographics of 790 students enrolled in the two \\
sections of the introductory biology course (90\% of total enroll- \\
ment) who provided the gender, ethnicity, and SAT score data that \\
were required for students to be included in the multiple linear \\
regression analyses in this study \\
\hline \multicolumn{2}{c}{ Number of students (\%) } \\
\hline Total & $790(100)$ \\
Gender & \\
Male & $236(29.9)$ \\
Female & $554(70.1)$ \\
Ethnicity & \\
White & $84(10.6)$ \\
Asian & $372(47.1)$ \\
Hispanic/Latin@ & $300(38.0)$ \\
African American & $34(4.3)$ \\
Major & \\
Biological sciences & \\
Other STEM (science, technology, engineering, & $173(21.9)$ \\
$\quad$ and mathematics) & \\
Non-STEM & $30(3.8)$ \\
Undecided/undeclared & $129(16.3)$ \\
Average SAT ( \pm SD) & $1648 \pm 198$ \\
\hline
\end{tabular}

class) by the course instructor (J.F.S.) and were posted on the course website at least 1 week before each day of class. Students were not required to complete the reading guides, which were not collected or rewarded points for completion; however, students were urged to complete them via an explanation in the syllabus and recommendations in lecture by the instructor (J.F.S.) and in discussion sections by the graduate teaching assistants. Sample reading guide questions are shown in Figure 1 , and all reading guides are located in the Supplemental Material.

The reading guides ranged from two to five pages long (average $\pm \mathrm{SD}=3.5 \pm 1.0, n=24$ ), with the most common length being three pages. The foundation of each reading guide involved asking students to answer questions or complete tasks in order to encourage them to actively read the textbook (Campbell Biology, 10th ed. [Reece et al., 2014]). Tasks included defining terms, explaining concepts, making tables and drawings, or answering in-chapter textbook questions (Figure 1). Students were directed which pages to read and what sections (if any) to skip. They were also directed to investigate specific figures or tables as deemed necessary. Completed reading guides were never posted to the course website or given to the students. However, students could ask questions about the reading guides on the course discussion board (Piazza, Palo Alto, CA) that were readily answered by the course instructor or teaching assistants.

\section{Data Collection}

Data were collected from students enrolled in two sections of the course taught during the Fall 2015 quarter. Section A (441 students enrolled) was taught from $12: 00 \mathrm{pm}$ to $12: 50 \mathrm{pm}$, and section B (436 students enrolled) was taught from 1:00 pm to 1:50 pm, with each class being taught on Monday, Wednesday, and Friday. To be eligible for this study and included in the analyses, a student had to consent to being in the study, had to be 18 years old at the beginning of the course, and had to have demographic information available (gender, ethnicity, and SAT scores). A total of 396 students (89.8\% of enrollment) from section A and 394 students (90.4\% of enrollment) from section $B$ met these conditions and were included in the analysis in this study (790 students total [90\%]). Demographic information for these students is provided in Table 1 . This study was approved by the University of California, Irvine Institutional Review Board (HS\# 2013-9833). Data were analyzed using Microsoft Excel 2011 (Microsoft, Redmond, WA) and the statistical program R, version 3.1.2 (R Foundation for Statistical Computing, Vienna, Austria).

\section{Reading Guide Use}

Two separate methods were used to determine how students used the reading guides in this course. First, students completed an online end of course survey via the course learning management system in which they answered questions relating to when they completed the reading guides (before class, after class, or not at all), how often they completed the reading guides before class (on a five-point scale from never to always), and how long they spent completing the reading guides on average (from 0 to $180+$ minutes). Second, students were asked to answer a clicker question (iClicker) at the start of each day of class regarding their completion of the reading guide associated with 


\begin{tabular}{|l|l|}
\hline Question type & Specific example \\
\hline Define term & $\begin{array}{l}\text { As you read about Mendel's experiments with pea plants, you will be } \\
\text { introduced to many new terms. Define the terms below, and give an } \\
\text { example (if applicable): Character, Trait, True-breeding, Hybridization }\end{array}$ \\
\hline $\begin{array}{l}\text { Explain concept or } \\
\text { process }\end{array}$ & $\begin{array}{l}\text { Explain how RNA processing alters the primary transcript to produce a final } \\
\text { mRNA molecule ready for translation. }\end{array}$ \\
\hline Compare and contrast & $\begin{array}{l}\text { Protein function is exquisitely linked to protein structure. Complete the } \\
\text { following table to compare the four levels of protein structure. See Figure } \\
5.18 \text { for help. }\end{array}$ \\
\hline Drawing & $\begin{array}{l}\text { Draw a typical eukaryotic cell, including all of the key structures that were } \\
\text { discussed in lessons 4, 5, 6, and 7. }\end{array}$ \\
\hline $\begin{array}{l}\text { Answer textbook } \\
\text { questions }\end{array}$ & $\begin{array}{l}\text { Answer concept check 49.2 questions 1, 2, and 3 on page 1090 in the space } \\
\text { below. }\end{array}$ \\
\hline $\begin{array}{l}\text { Prepare for online pre- } \\
\text { class assignment }\end{array}$ & $\begin{array}{l}\text { Read and analyze the "scientific skills exercise" on page 248. You will be } \\
\text { answering the questions associated with this exercise as part of your pre- } \\
\text { class assignment. }\end{array}$ \\
\hline
\end{tabular}

FIGURE 1. Examples of reading guide questions from throughout the course. The type of question is shown along with an example for each.

that day of class. Approximately 3 minutes after the start of each day of class, the following clicker question was posed: "How did you prepare for class today?" Students could answer "A-I completed the entire reading guide," "B-I completed more than half of the reading guide, but not all of it," "C-I completed less than half of the reading guide," "D-I did not complete the reading guide at all, but I still read the assigned textbook pages," or "E-I did not complete the reading guide at all and I did not read the assigned textbook pages." Student responses to these questions required them to be present in class and have their iClicker device with them. The percent of responses ranged from a maximum of $98.4 \%$ of enrollment to a minimum of $75.1 \%$ of enrollment. The overall average percentage of responses on a given day of class to this question was $90.7 \pm 4.9 \%$ of enrollment.

To determine the accuracy of students' self-reported use of the reading guides via daily clicker questions, graduate student teaching assistants randomly examined students' reading guides in discussion sections. Without notifying the students ahead of time, two graduate teaching assistants examined students' reading guides in their discussion sections, which were held 2 to 4 hours before lecture started. The teaching assistants noted the extent to which the students had completed their reading guides, and this was compared with the degree of completion that the students input during the in-class clicker question to determine whether students reported the same level of completion, underreported how much they had completed, or overreported how much they had completed. Data were collected randomly from 62 students throughout the course in this manner.

\section{Reading Guide Completion and Examination Performance}

Multiple linear regression models were used to determine the impact of reading guides on student performance, because these models control for extraneous factors that may affect interpretation of the results (Theobald and Freeman, 2014). Models were developed with the response variables being student performance on each of the four exams as a percentage out of 100. The data for both sections were combined, and thus four models were developed in this analysis (one for each exam). The total exam scores (as a percentage out of 100) on midterm exams 1,2 , and 3 were used as response variables in their respective models. The final exam was split into two sections: half on the new material and half on the past material covered in the three midterms. The score on the "new" portion of the final exam (as a percentage out of 100) was used as the response variable for the final exam model. Descriptive statistics for student performance on each exam (as a percentage out of 100) are shown in Table 2.

The impact that reading guide completion may have on student performance was determined in the following manner. Students' answers to the daily clicker question about reading guide completion were examined for how many times over the course of the class that a student responded "A-I completed the entire reading guide" and were summed. Each exam covered six new lessons; therefore, the maximum number of times a student could respond "A" was six (for the six lessons of the class), and the minimum was zero. This explanatory variable was therefore treated as a continuous variable with a value of $0-6$ in the models. The average numbers of reading guides that students completed fully before class for each exam are shown in Table 2. To be included in these analyses, students had to attend class and respond to the daily clicker question all 6 days of class covered on each exam. This requirement limited our data set, as students had to routinely attend class and answer the clicker question each day. The final numbers for students included in each model are presented in Table 2. The total number of students in each model ranged from 602 (exam 1; 76\% of the study sample) to 426 (final exam; $53 \%$ of the study sample). The number of students included in the final exam model was low, because this set of six lessons included a lesson the day before Thanksgiving, and many students did not attend (attendance on that day was only $75 \%$, the lowest of the course). To summarize, we are focusing in these analyses on the extent that full completion of reading guides before class contributes to exam performance. We did not assess the impacts of partial reading guide completion on performance in this study.

In addition to the number of reading guides, several other explanatory variables were included in this analysis to attempt to control for confounding factors. Students' average preclass assignment scores that corresponded for a particular exam were included to control for any effect that completion of the preclass

TABLE 2. Descriptive data for exams taken by students included in each model in the analysis

\begin{tabular}{lccc}
\hline Exam & $\begin{array}{c}\text { Average exam } \\
\text { score }( \pm \text { SD) }\end{array}$ & $\begin{array}{c}\text { Average number of } \\
\text { reading guides completed } \\
\text { fully before class }( \pm \text { SD) }\end{array}$ & $\begin{array}{c}n \text { (percent } \\
\text { of study } \\
\text { sample) }\end{array}$ \\
\hline 1 & $70.83 \pm 18.02$ & $3.61 \pm 2.04$ & $602(76)$ \\
2 & $63.23 \pm 16.65$ & $2.56 \pm 2.28$ & $570(72)$ \\
3 & $71.42 \pm 15.55$ & $2.97 \pm 2.22$ & $523(66)$ \\
Final & $65.82 \pm 16.15$ & $3.07 \pm 2.19$ & $426(53)$ \\
\hline
\end{tabular}

${ }^{\mathrm{a} E a c h}$ exam score is presented as an average out of $100 \%$.

${ }^{\mathrm{b}}$ The average number of reading guides that students completed fully before class (out of a maximum of six per exam) is shown for each exam. 
assignments may have on examination performance. SAT math and reading scores were included to control for student aptitude (SAT writing scores were not included, as they were not found to significantly contribute to the models). Student demographic factors, including gender and ethnicity (treated as a binary variable as URM [African-American, Latin@, or Native American] or majority [Asian or white]), were also included to account for any demographic influence. Because the data from both sections of the course were combined, a binary variable for course section was also included. The final model was

Exam performance $=$ number of reading guides completed fully before class + preclass assignment score + SAT math + SAT reading + gender + ethnicity + section

\section{Reading Guide Completion among Student Groups}

Multiple linear regression models were also used to determine whether different student groups (based on gender, ethnicity, or SAT scores) completed the reading guides before class to different extents. Models were created using the number of reading guides completed fully before class as the response variable and student gender, ethnicity, SAT math score, SAT reading score, and course section as the explanatory variables. Student usage was analyzed for each individual exam (six reading guides per exam). The final model was

Number of reading guides completed fully before class $=$ SAT math + SAT reading + gender + ethnicity + section

Only students who had complete data for all of the above-mentioned variables were included in each of the four models. Estimates for each variable in the model were reported as mean \pm SEM and were considered statistically significant at $p<0.05$.

\section{RESULTS}

\section{Reading Guide Use}

Student use of the reading guides was measured through an end of course survey. A total of 677 students completed this survey. First, students were asked whether they completed the reading guides before class, after class, or not at all. From this survey, $\sim 86 \%$ of students reported that they completed the reading guides at least sometimes before class. Approximately $9 \%$ of students reported that they completed the reading guides after class, while $\sim 5 \%$ reported that they did not complete them at all. Next, students were asked to report on a five-point scale from "never" to "always" to determine how often they completed the reading guides before class (again, this was the way we recommended reading guides be used). As shown in Figure 2A, $>86 \%$ of students reported completing the reading guides at least sometimes before class. Finally, we sought to determine how much time students spent completing the reading guides before class. As shown in Figure 2B, students reported a wide range of times, with the most common time being 60-90 minutes per reading guide.

Students' daily clicker responses were analyzed to examine student reading guide use at a more granular level. Figure 3 shows the average percent responses to each of the five clicker question options over the entire course. On average, $>75 \%$ of students reported completing at least some of the reading guide for a given day of class, with nearly 50\% reporting that they completed the entire reading guide before class each day. The daily clicker responses were also analyzed to determine the average number of reading guides the students completed fully before class (i.e., "A-I completed the entire reading guide") for different time periods in the course. As shown in Table 2, the average number of reading guides that students completed fully before class for each exam period (maximum of six reading guides per exam) varied across the duration of the course.

To determine whether different student groups (based on gender, ethnicity, and SAT math and reading scores) fully completed reading guides similarly before class, we developed multiple linear regression models using the number of reading guides completed fully before class (i.e., the number of times that a student responded " $\mathrm{A}-\mathrm{I}$ completed the entire reading guide") as the response variable and student gender, ethnicity, SAT math scores, SAT reading scores, and course section as the explanatory variables. Table 3 presents these models for each individual exam. Student demographics significantly contributed to reading guide completion before class in few cases and in an inconsistent manner.
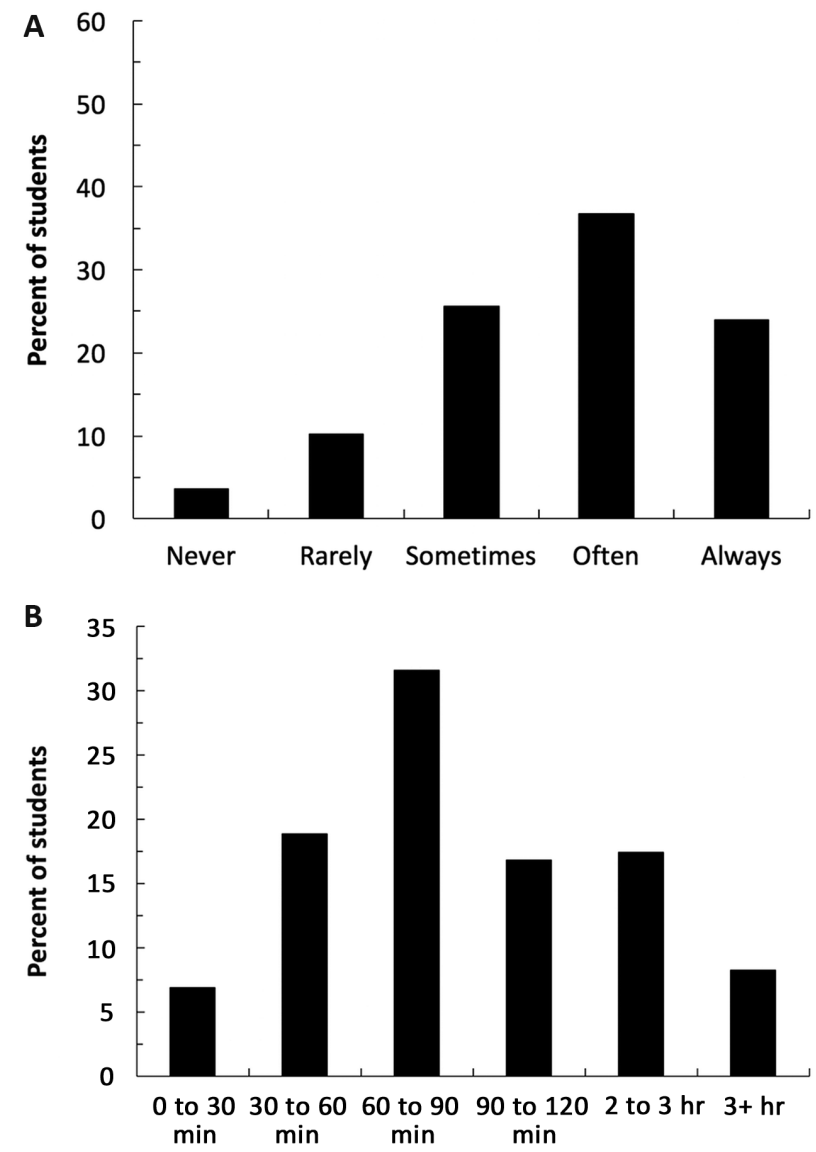

FIGURE 2. Summary of student use of the reading guides from end of course survey data. Students reported how often they completed reading guides before class $(A)$ and the average time they spent completing the reading guides (B). 


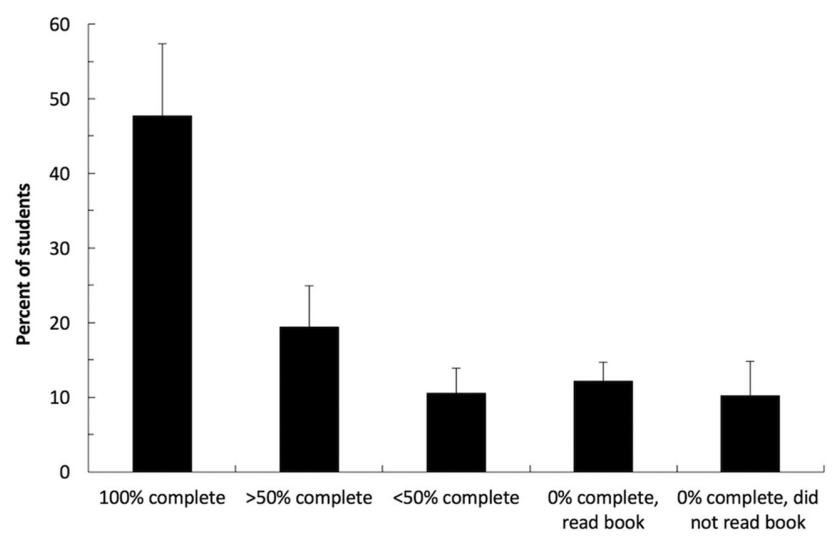

FIGURE 3. Summary of daily clicker response data to assess what proportion of the reading guides students completed before class. Data are presented as mean \pm SD for the entire course.

\section{Impacts of Reading Guides on Exam Performance}

To determine the impact that completing reading guides fully before class (i.e., the number of times that a student responded "A-I completed the entire reading guide") had on exam performance (as a percentage out of 100), multiple linear regression models were constructed controlling for potential confounding factors (gender, ethnicity, SAT math score, SAT reading score, preclass assignment scores, and course section). Table 4 displays the models for each exam in the course. To be included in these models, a student had to attend all lessons covered on each exam (six each) and had to answer the clicker question in each day of class. The model estimates for the impact of completing a single reading guide before class on exam score varied from a low of $1.35 \pm 0.26$ (exam 3) to a high of $1.71 \pm 0.26$ (exam 2). The estimates for completing reading guides before class were statistically significant $(p<0.05)$ for each of the four exams when controlling for the potentially confounding factors listed earlier (the other factors that significantly contributed to each model are shown in Table 4). SAT math and reading scores contributed significantly to nearly every model, and gender and ethnicity contributed in a few cases.

Based on these results, completing reading guides fully before class contributed significantly to exam performance.
Taking the most conservative estimate (the model output from exam 3), completing a single reading guide before class yielded a gain of $1.35 \pm 0.26$ percentage points (out of 100) on the exam. Therefore, if a student completed all six reading guides, the model predicts that his or her exam score would be $\sim 6.5-9.6$ points (out of 100) higher than if the student completed zero reading guides (controlling for other demographic factors). This corresponds to a half-letter grade to full-letter grade improvement on the exam.

\section{Comparison of Students Included in the Models}

For students to be included in the multiple linear regression models, they had to attend all six lessons associated with a given exam and respond to the clicker question each day. Because of this requirement, many students were left out of each model. As shown in Tables 3 and 4, the number of students included in each model ranged from 76 to $53 \%$ of the study sample. Because of this loss of the study sample, there is potential for a bias in the analysis and results in this study toward those students who met the conditions. To determine whether the demographics of students included in each model were significantly different from those not included in each model, chi-square tests were performed between the two groups on the basis of gender and ethnicity for each of the four exams. In addition, paired $t$ tests were performed on the average total SAT scores between the two groups for each exam. There were no significant differences between gender, ethnicity, or SAT distributions between students in the model versus those not in the model for any exam (Supplemental Tables S1-S3).

\section{Validation of Reading Guide Self-Report Data}

The reading guide usage data obtained in this study hinge on the accuracy of the student self-reports from the daily clicker questions. To validate these data, graduate teaching assistants randomly reviewed students' reading guides in discussion sections before class and indicated the extent to which the students' completed the reading guides. Over the duration of the class, 62 students' reading guides were examined and were compared with their self-reported reading guide completion results from the lecture portion of the course. Analysis of these data showed that $69.4 \%$ of the teaching assistant observations

TABLE 3. Multiple linear regression analyses of the effects of student demographics on the number of reading guides a student completed fully before class for each exam ${ }^{\text {a }}$

\begin{tabular}{|c|c|c|c|c|c|c|c|c|}
\hline \multirow[b]{2}{*}{ Regression coefficient } & \multicolumn{2}{|c|}{$\begin{array}{c}\text { Exam } 1 \\
(n=602 ; 76 \%)\end{array}$} & \multicolumn{2}{|c|}{$\begin{array}{c}\text { Exam } 2 \\
(n=570 ; 72 \%)\end{array}$} & \multicolumn{2}{|c|}{$\begin{array}{c}\text { Exam } 3 \\
(n=523 ; 66 \%)\end{array}$} & \multicolumn{2}{|c|}{$\begin{array}{c}\text { Final Exam } \\
(n=416 ; 53 \%)\end{array}$} \\
\hline & Estimate \pm SEM & $p$ value & Estimate \pm SEM & $p$ value & Estimate \pm SEM & $p$ value & Estimate \pm SEM & $p$ value \\
\hline Model intercept & $2.32 \pm 0.72$ & 0.001 & $1.71 \pm 0.86$ & 0.05 & $1.38 \pm 0.85$ & 0.10 & $2.86 \pm 0.97$ & 0.003 \\
\hline Gender (male) & $-0.62 \pm 0.19$ & 0.001 & $0.02 \pm 0.22$ & 0.91 & $-0.24 \pm 0.22$ & 0.27 & $0.16 \pm 0.25$ & 0.51 \\
\hline Ethnicity (majority) & $-0.09 \pm 0.19$ & 0.62 & $0.50 \pm 0.22$ & 0.02 & $0.18 \pm 0.22$ & 0.41 & $0.30 \pm 0.24$ & 0.22 \\
\hline SAT math & $0.002 \pm 0.001$ & 0.11 & $0.0005 \pm 0.002$ & 0.73 & $0.004 \pm 0.002$ & 0.01 & $0.002 \pm 0.002$ & 0.20 \\
\hline SAT reading & $0.0006 \pm 0.001$ & 0.66 & $0.0008 \pm 0.001$ & 0.57 & $-0.001 \pm 0.001$ & 0.48 & $-0.002 \pm 0.002$ & 0.21 \\
\hline Section (B) & $-0.007 \pm 0.17$ & 0.97 & $-0.43 \pm 0.19$ & 0.02 & $-0.43 \pm 0.19$ & 0.03 & $-0.43 \pm 0.21$ & 0.04 \\
\hline Adjusted $R^{2}$ & \multicolumn{2}{|c|}{0.013} & \multicolumn{2}{|c|}{0.018} & \multicolumn{2}{|c|}{0.026} & \multicolumn{2}{|c|}{0.018} \\
\hline
\end{tabular}

aThere was a maximum of six reading guides for each exam. The reference levels for these models are female, underrepresented minority, and section A. The number of students $(n)$ included in each model is listed with the percentage of the study sample that was included in the model in parentheses. 
Reading Guides for Introductory Biology

TABLE 4. Multiple linear regression analyses exploring the impacts of the number of reading guides a student fully completed before class on exam performance ${ }^{a}$

\begin{tabular}{|c|c|c|c|c|c|c|c|c|}
\hline \multirow[b]{2}{*}{ Regression coefficient } & \multicolumn{2}{|c|}{$\begin{array}{c}\text { Exam } 1 \\
(n=602 ; 76 \%)\end{array}$} & \multicolumn{2}{|c|}{$\begin{array}{c}\text { Exam } 2 \\
(n=570 ; 72 \%)\end{array}$} & \multicolumn{2}{|c|}{$\begin{array}{c}\text { Exam } 3 \\
(n=523 ; 66 \%)\end{array}$} & \multicolumn{2}{|c|}{$\begin{array}{c}\text { Final Exam } \\
(n=426 ; 54 \%)\end{array}$} \\
\hline & Estimate \pm SEM & $p$ value & Estimate \pm SEM & $p$ value & Estimate \pm SEM & $p$ value & Estimate \pm SEM & $p$ value \\
\hline Model intercept & $-39.20 \pm 9.56$ & 4.69e-05 & $-22.87 \pm 7.09$ & 0.001 & $-14.79 \pm 6.98$ & 0.04 & $-16.54 \pm 9.52$ & 0.08 \\
\hline Total number of reading guides & $1.59 \pm 0.30$ & $1.29 \mathrm{e}-07$ & $1.71 \pm 0.26$ & $7.59 \mathrm{e}-11$ & $1.35 \pm 0.26$ & $3.32 \mathrm{e}-07$ & $1.54 \pm 0.30$ & $3.44 \mathrm{e}-07$ \\
\hline Preclass assignment score & $0.28 \pm 0.09$ & 0.002 & $0.17 \pm 0.06$ & 0.003 & $0.18 \pm 0.06$ & 0.002 & $0.24 \pm 0.09$ & 0.006 \\
\hline Gender (male) & $1.82 \pm 1.35$ & 0.18 & $4.25 \pm 1.34$ & 0.002 & $1.85 \pm 1.28$ & 0.15 & $4.06 \pm 1.50$ & 0.007 \\
\hline Ethnicity (majority) & $3.25 \pm 1.34$ & 0.015 & $1.29 \pm 1.35$ & 0.34 & $0.88 \pm 1.28$ & 0.50 & $1.47 \pm 1.48$ & 0.32 \\
\hline SAT math & $0.08 \pm 0.01$ & $<2 \mathrm{e}-16$ & $0.06 \pm 0.01$ & $9.14 \mathrm{e}-11$ & $0.08 \pm 0.01$ & $<2 \mathrm{e}-16$ & $0.06 \pm 0.01$ & $4.81 \mathrm{e}-09$ \\
\hline SAT reading & $0.05 \pm 0.01$ & $2.16 \mathrm{e}-08$ & $0.05 \pm 0.01$ & $5.88 \mathrm{e}-09$ & $0.03 \pm 0.01$ & 0.001 & $0.04 \pm 0.01$ & $4.58 \mathrm{e}-05$ \\
\hline Section (B) & $0.36 \pm 1.18$ & 0.76 & $1.96 \pm 1.15$ & 0.09 & $4.82 \pm 1.13$ & $2.51 \mathrm{e}-05$ & $-4.59 \pm 1.30$ & $4.64 \mathrm{e}-04$ \\
\hline Adjusted $R^{2}$ & \multicolumn{2}{|c|}{0.380} & \multicolumn{2}{|c|}{0.344} & \multicolumn{2}{|c|}{0.358} & \multicolumn{2}{|c|}{0.345} \\
\hline
\end{tabular}

aThe model estimates (mean \pm SEM) for the impact of the full completion of a single reading guide before class on exam scores (out of $100 \%$ ) are provided for each exam as well as for other variables. The reference levels for these models are female, underrepresented minority, and section A. The number of students ( $n$ ) included in each model is listed with the percentage of the study sample that was included in the model in parentheses.

matched the students' self-reports, $14.5 \%$ of the students overreported their completion of the reading guides, and $16.1 \%$ underreported their completion of the reading guides.

\section{DISCUSSION}

This study assessed the impact of optional, preclass textbook reading guides on exam performance in two sections of a large-enrollment $(400+)$ undergraduate introductory biology course. Our results showed that on average $\sim 80 \%$ of students completed at least some of the reading guides before class (with $\sim 50 \%$ completing the entire reading guide each time [i.e., for each day of class]). When controlling for potentially confounding factors, full completion of reading guides before class was significantly positively correlated with increased exam scores for all exams in the course. In addition, the reading guides seemed to be used equivalently by different student groups (based on gender, ethnicity, and SAT scores), suggesting that the use of reading guides did not exclude any students from potential benefits. These results are significant because they suggest that a relatively simple, low-stakes intervention such as preclass reading guides can be implemented in a large-enrollment biology course to encourage students to read their textbooks and help students stay on track on a daily basis, resulting in a significant positive impact on student learning.

While these results demonstrate that optional preclass reading guides are significantly positively correlated with increased exam scores, they do not provide evidence regarding the mechanism of why reading guides may result in improved performance. However, two hypotheses seem likely. It could be that the reading guides are helping students read and understand the textbook. Completing a reading guide requires students to take an active approach to reading the textbook through pausing to answer questions in their own words, to examine figures, to complete tables, and so on. Indeed, several studies have highlighted the importance of textbook reading strategies that can result in increased reading comprehension (Simpson and Nist, 1990; Digisi and Willett, 1995; Best et al., 2005; Ozuru et al., 2009). Alternatively, it could be that the reading guides served as a way to help students stay on track on a daily basis and thus helped students manage their studying throughout the course. By reading the textbook before class and answering questions in the reading guide, students are exhibiting retrieval practice behaviors, which have been shown to be positively related to learning and performance (Roediger and Karpicke, 2006; Butler and Roediger, 2007; Karpicke and Blunt, 2011; Pennebaker et al., 2013). One possibility that is not likely, however, is that students improved on exams because they were answering verbatim or very similar questions from the reading guides on the exams themselves. While the exams in the courses in this study contained greater than $60 \%$ Bloom's level-three (application) and higher questions, the reading guides contained mostly Bloom's level-one (knowledge) and level-two (comprehension) questions. Moreover, no exam questions were identical to any reading guide questions (all exams and reading guides are provided in the Supplemental Material). Therefore, it is possible that the solid foundation in lower-level Bloom's skills provided by the reading guides enabled students to develop their higher-level Bloom's skills in class and thus apply them to exams. Future studies are warranted to investigate the mechanism of how reading guides may lead to improved learning and success.

The results from this study are based on a single reading guide structure that requires students to define terms, explain concepts, complete tables, make drawings, and answer in-chapter questions. However, the reading guide structure could be modified to achieve even larger gains in future courses by including other activities, such as concept mapping, drawing, and question authoring that have been shown to support student learning (Novak, 1990; Van Meter, 2001; Van Meter et al., 2006; Hay et al., 2008; Bottomley and Denny, 2011; McQueen et al., 2014). Additionally, the reading guides could be modified such that students complete them in groups online (via Google Docs or similar products), which may yield beneficial results (Blau and Caspi, 2009; Chu and Kennedy, 2011). Finally, the implementation of the reading guides could be modified so that they are required and worth course points. This change in grading policy will likely increase the completion rate, but with large courses such as the one in this study (400+ students in each section), collection and grading of the reading guides may be problematic. 
However, the potential benefits may outweigh the costs in this scenario. It is therefore worthwhile to explore alternative reading guide structures and implementations to determine what structure provides the best learning opportunity for students.

\section{Implementing Reading Guides in Other Courses}

While the results of this study are promising, they were found by examining students from a single large R1 university in the western United States. Moreover, the course was taught primarily for majors, with a specific textbook (Campbell Biology, 10th ed. [Reece et al., 2014]), and in the 10-week quarter system. Therefore, replication of these results at other types of institutions with other students and courses is critical. To this end, we wish to offer some advice for instructors who may wish to adopt reading guides for use in their courses. First, a significant time commitment is required to develop them, no matter what textbook is used. The correct page numbers, section titles, and figures must be cited, and specific questions that go along with the textbook need to be written. This could also lead to problems when a new edition of the textbook is published, as the reading guides may need to be updated to reflect changes in the textbook. However, by going through the act of developing reading guides, we found that we were much more in tune with the content of the textbook and were very clear on what we wanted students to read in advance of each class session, which helped align learning objectives between preclass assignments and in-class activities (Biggs, 2003; Handelsman et al., 2007). Additionally, students must have the time to be able to complete the reading guides. We found $\sim 1 / 3$ of our students spent 60-90 minutes completing a single reading guide, with $\sim 70 \%$ spending between 30 and 120 minutes per reading guide (Figure 2B). If students already have significant demands on their time from course work or other commitments, expecting students to complete reading guides may be too much to demand. Second, once the reading guides are developed, what happens in each class session may need to change so as to hold students accountable for completing the reading before class. Instead of spending time defining terms, explaining basic concepts, or going through textbook examples verbatim, an instructor may wish to first ask the class questions about the definitions or basic concepts to determine whether students did indeed acquire the necessary content from the reading. In this way, significant portions of content delivery can be removed from class, thus freeing up time to challenge students to apply what they have read through the use of problem-based learning, case studies, or primary literature data analysis (Allen and Tanner, 2005; Allen et al., 2011; Herreid, 2007; Hoskins et al., 2011; Round and Campbell, 2013). Third, we advise that the completed reading guides not be posted for students to download, as we fear that students may choose to simply study the completed document without actually reading the textbook. However, students may be encouraged to post questions regarding the reading guides to a course discussion board or to collaborate with classmates. Finally, we recommend incorporating the reading guides into in-class activities. For example, when discussing the stages of cellular respiration in class, we ask students to take out their reading guides and compare their work with each other. This achieves two goals: first, it helps students specifically review content that is required for in-class activities, and second, it demonstrates to students that the reading guides are important and should be completed before class as they will help the students succeed in class.

\section{Limitations}

A confounding factor of this study is that we did not directly measure and control for student motivation. It is possible that the students who completed the reading guides before class and arrived to class on time were more motivated and would have performed well on exams no matter what instructional tools were available to them. Thus, the daily clicker question asking about reading guide completion could have been capturing motivation. As we know that motivation is strongly associated with learning (Preckel et al., 2006; Schunk and Zimmerman, 2008; Bryan et al., 2011), this possibility cannot be ruled out. However, we attempted to control for motivation by only including students who attended all 6 days of class associated with each exam. In this case, students had to be at least equally motivated to attend each day of class (and thus they also received identical instruction). We also included preclass assignment scores in each model in an attempt to control for student motivation to complete these assignments.

Another limitation is that our conclusions are based on the analysis of student self-reported data (the daily clicker questions that assessed reading guide completion). We attempted to determine how accurate students' clicker responses were through visual inspection of students' reading guides in discussion sections held 2 to 4 hours before a given lecture period. Through this method, we found that $\sim 70 \%$ of students accurately reported their degree of reading guide completion, and $\sim 15 \%$ each either overreported or underreported how much of the reading guide they completed. Accuracy of self-reported data is a concern in many fields, including education research, medicine, health services, and other social sciences, as conclusions critically depend on the quality of the data (Koziol and Burns, 1986; Zapka et al., 1996; Del Boca and Noll, 2000; Okura et al., 2004; Connor Gorber et al., 2007; Boufous et al., 2010). One such example about the concerns of the accuracy of self-report data is available from educational research literature: a meta-analysis that showed that the accuracy rate of students self-reporting their high school or college grade point average varied from a low of $54.3 \%$ to a high of $82.4 \%$ (Kuncel et al., 2005).

Students may choose to self-report inaccurate information for a variety of reasons, but the concept of socially desirable response theory may apply in our situation. Socially desirable response theory states that people tend to tailor their responses to surveys in order to be viewed favorably by others (Edwards, 1957; Crowne and Marlowe, 1960). In this case, students may have chosen to overreport the amount of the reading guide that they completed because that would be viewed more favorably by their peers and their instructors. This explanation would account for the $\sim 15 \%$ who indeed overreported their reading guide completion. Alternatively, the students who overreported their reading guide completion may have actually completed the reading guide in between the time that their reading guide was checked and the time that class started (a 1- to 3-hour window). On the other hand, students who underreported their reading guide completion may have underestimated how much they actually completed (perhaps by not being sure where the halfway point of the reading guide was). Finally, students 
may simply have forgotten or accidentally misrepresented the amount of the reading guide that they completed.

Regardless of the reasons why students did not provide completely accurate data, we found that $\sim 70 \%$ of students reported accurate data, leaving a potential error of $\sim 30 \%$ in the self-report data. A possible way to account for this error is to carry it through to the multiple linear regression model results. By doing so we could expect a possible $30 \%$ change in the model estimates for the impacts of fully completing reading guides before class (Table 4). In the most conservative example, a 30\% reduction in the lowest model estimate (that from exam 3; Table 4) would be $0.95 \pm 0.26$ percentage points (out of 100 ) on the exam, which is still nearly a full percentage point gained by fully completing one reading guide before class. Using this most conservative revised estimate, a student who completed all six reading guides would be predicted to earn $\sim 4.1-7.3$ points (out of 100) higher on his or her exam than if the student completed zero reading guides (controlling for other demographic factors). Therefore, even when accounting for a possible 30\% error, full completion of reading guides before an exam may yield approximately a half-letter grade improvement on an exam. Further studies are necessary to determine the reasons for inaccuracies in self-report data in studies such as this and the impacts of self-report inaccuracies on model outcomes.

\section{CONCLUSIONS}

In conclusion, optional preclass reading guides were used in a large-enrollment introductory biology course to assist students in reading the textbook. The results suggest that, in our course and with our student population, full completion of reading guides before class is significantly positively correlated with exam performance; however, the mechanism behind this result cannot be determined from this study. Future studies are warranted to investigate the reasons why reading guide completion is positively correlated with exam performance and to determine whether varying reading guide structure or implementation differentially affects student learning.

\section{ACKNOWLEDGMENTS}

We thank Kelly Hogan for inspiration in designing our reading guides. We also thank Brian Sato, Adrienne Williams, and Pavan Kadandale for helpful discussions regarding this study and for reviews of this article.

\section{REFERENCES}

Allen, D., \& Tanner, K. (2005). Infusing active learning into the large-enrollment biology class: Seven strategies, from the simple to complex. Cell Biology Education, 4, 262-268.

Allen, D. E., Donham, R. S., \& Bernhardt, S. A. (2011). Problem-based learning New Directions for Teaching and Learning, 2011, 21-29.

American Association for the Advancement of Science. (2011). Vision and change in undergraduate biology: A call to action. Washington, DC.

Armbruster, P., Patel, M., Johnson, E., \& Weiss, M. (2009). Active learning and student-centered pedagogy improve student attitudes and performance in introductory biology. CBE-Life Sciences Education, 8, 203-213.

Berry, T., Cook, L., Hill, N., \& Stevens, K. (2011). An exploratory analysis of textbook usage and study habits: Misperceptions and barriers to success. College Teaching, 59, 31-39.

Best, R. M., Rowe, M., Ozuru, Y., \& McNamara, D. S. (2005). Deep-level comprehension of science texts-The role of the reader and the text. Topics in Language Disorders, 25, 65-83.
Biggs, J. (2003). Aligning teaching for constructing learning. Higher Education Academy, 1-4

Blau, I., \& Caspi, A. (2009). Sharing and collaborating with Google Docs: The influence of psychological ownership, responsibility, and student's attitudes on outcome quality. In Bastiaens, T., Dron, J., \& Xin, C. (Eds.), Proceedings of E-Learn: World Conference on E-Learning in Corporate, Government, Healthcare, and Higher Education 2009 (pp. 3329-3335). Chesapeake, VA: Association for the Advancement of Computing in Education (AACE)

Bloom, B. S., Krathwohl, D. R., \& Masia, B. B. (1956). Taxonomy of educational objectives: The classification of educational goals. New York: McKay.

Bonwell, C. C., \& Eison, J. A. (1991). Active learning: Creating excitement in the classroom (ASHE-ERIC Higher Education Report). Washington, DC: School of Education and Human Development, George Washington University.

Bottomley, S., \& Denny, P. (2011). A participatory learning approach to biochemistry using student authored and evaluated multiple-choice questions. Biochemistry and Molecular Biology Education, 39, 352-361.

Boufous, S., Ivers, R., Senserrick, T., Stevenson, M., Norton, R., \& Williamson, A. (2010). Accuracy of self-report of on-road crashes and traffic offences in a cohort of young drivers: The DRIVE study. Injury Prevention, 16, 275-277.

Bryan, R. R., Glynn, S. M., \& Kittleson, J. M (2011). Motivation, achievement, and advanced placement intent of high school students learning science. Science Education, 95, 1049-1065

Butler, A. C., \& Roediger, H. L. (2007). Testing improves long-term retention in a simulated classroom setting. European Journal of Cognitive Psychology, 19, 514-527.

Chu, S. K. W., \& Kennedy, D. M. (2011). Using online collaborative tools for groups to co-construct knowledge. Online Information Review, 35, 581-597.

Clump, M. A., Bauer, H., \& Bradley, C. (2004). The extent to which psychology students read textbooks: A multiple class analysis of reading across the psychology curriculum. Journal of Instructional Psychology, 31, 227-232.

Connor Gorber, S., Tremblay, M., Moher, D., \& Gorber, B. (2007). A comparison of direct vs. self-report measures for assessing height, weight and body mass index: A systematic review. Obesity Reviews, 8, 307-326.

Crowne, D., \& Marlowe, D. (1960). A new scale of social desirability independent of psychopathology. Journal of Consulting Psychology, 24, 349354.

Del Boca, F. K., \& Noll, J. A. (2000). Truth or consequences: The validity of self-report data in health services research on addictions. Addiction, 95(suppl 3), S347-S360.

Digisi, L. L., \& Willett, J. B. (1995). What high-school biology teachers say about their textbook use-A descriptive study. Journal of Research in Science Teaching, 32, 123-142.

Eddy, S. L., \& Hogan, K. A. (2014). Getting under the hood: How and for whom does increasing course structure work? CBE-Life Sciences Education, 13, 453-468.

Edwards, A. (1957). The social desirability variable in personality assessment and research. New York: Dryden.

Elshout-Mohr, M., \& van Daalen-Kapteijns, M. (2002). Situated regulation of scientific text processing. In Otero, J., Leon, L. A., \& Graesser, A. C. (Eds.), The psychology of science text comprehension (pp. 223-252). Mahwah, NJ: Erlbaum.

Esper, S., Simon, B., \& Cutts, Q. (2012). Exploratory homeworks: An active learning tool for textbook reading. International Computing Education Research, 105-110.

Fang, Z. (2006). The language demands of science reading in middle school. International Journal of Science Education, 28, 491-520.

Freeman, S., Haak, D., \& Wenderoth, M. P. (2011). Increased course structure improves performance in introductory biology. CBE-Life Sciences Education, 10, 175-186.

Groves, F. (1995). Science vocabulary load of selected secondary science textbooks. School Science and Mathematics, 95, 231-235.

Handelsman, J., Miller, S., \& Pfund, C. (2007). Scientific teaching. New York: Freeman.

Hay, D., Kinchin, I., \& Lygo-Baker, S. (2008). Making learning visible: The role of concept mapping in higher education. Studies in Higher Education, 33, 295-311. 
Heiner, C. E., Banet, A. I., \& Wieman, C. (2014). Preparing students for class: How to get $80 \%$ of students reading the textbook before class. American Journal of Physics, 82, 989-996.

Herreid, C. F. (2007). Start with a story: The case study method of teaching college science. Arlington, VA: NSTA Press.

Hodges, L. C. (2015). Teaching undergraduate science: A guide to overcoming obstacles to student learning. Sterling, VA: Stylus.

Hoskins, S. G., Lopatto, D., \& Stevens, L. M. (2011). The CREATE approach to primary literature shifts undergraduates' self-assessed ability to read and analyze journal articles, attitudes about science, and epistemological beliefs. CBE-Life Sciences Education, 10, 368-378.

Jensen, J. L., Kummer, T. A., \& Godoy, PDDM (2015). Improvements from a flipped classroom may simply be the fruits of active learning. CBE-Life Sciences Education, 14, ar5.

Karpicke, J. D., \& Blunt, J. R. (2011). Retrieval practice produces more learning than elaborative studying with concept mapping. Science, 331, 772-775.

Koziol, S. Jr., \& Burns, P. (1986). Teachers' accuracy in self-reporting about instructional practices using a focused self-report inventory. Journal of Educational Research, 79, 205-209.

Kuncel, N., Crede, M., \& Thomas, L. L. (2005). The validity of self-reported grade point averages, class ranks, and test scores: A meta-analysis and review of the literature. Review of Educational Research, 75, 63-82.

McQueen, H. A., Shields, C., Finnegan, D. J., Higham, J., \& Simmen, M. W. (2014). PeerWise provides significant academic benefits to biological science students across diverse learning tasks, but with minimal instructor intervention. Biochemistry and Molecular Biology Education, 42, 371-381.

Milman, N. B. (2012). The flipped classroom strategy: What is it and how can it be best be used? Distance Learning, 9, 85-87.

Novak, J. D. (1990). Concept mapping-A useful tool for science education. Journal of Research in Science Teaching, 27, 937-949.

O'Flaherty, J., \& Phillips, C. (2015). The use of flipped classrooms in higher education: A scoping review. Internet Higher Education, 25, 85-95.

Okura, Y., Urban, L. H., Mahoney, D. W., Jacobsen, S. J., \& Rodeheffer, R. J. (2004). Agreement between self-report questionnaires and medical record data was substantial for diabetes, hypertension, myocardial infarction and stroke but not for heart failure. Journal of Clinical Epidemiology, 57, 1096-1103.

Ozuru, Y., Dempsey, K., \& McNamara, D. S. (2009). Prior knowledge, reading skill, and text cohesion in the comprehension of science texts. Learning and Instruction, 19, 228-242.

Pennebaker, J. W., Gosling, S. D., \& Ferrell, J. D. (2013). Daily online testing in large classes: Boosting college performance while reducing achievement gaps. PLoS One, 8(11), e79774.

Podolefsky, N. S., \& Finkelstein, N. (2006). The perceived value of college physics textbooks: Students and instructors may not see eye to eye. Physics Teacher, 44, 338-342.

Preckel, F., Holling, H., \& Vock, M. (2006). Academic underachievement: Relationship with cognitive motivation, achievement motivation, and conscientiousness. Psychology in the Schools, 43, 401-411.
President's Council of Advisors on Science and Technology. (2012). Engage to excel: Producing one million additional college graduates with degrees in science, technology, engineering, and mathematics. Washington, DC: U.S. Government Office of Science and Technology.

Reece, J. B., Urry, L. A., Cain, M. L., Wasserman, S. A., Minorsky, P. V., \& Jackson, R. B. (2014). Campbell biology (10th ed.). Upper Saddle River, $\mathrm{NJ}$ : Pearson Education.

Roediger, H. L., \& Karpicke, J. D. (2006). Test-enhanced learning-Taking memory tests improves long-term retention. Psychological Science, 17, $249-255$.

Round, J. E., \& Campbell, A. M. (2013). Figure facts: Encouraging undergraduates to take a data-centered approach to reading primary literature. CBE-Life Sciences Education, 12, 39-46.

Schunk, D. H., \& Zimmerman, B. J. (2008). Motivation and self-regulated learning: Theory, research, and applications. New York: Erlbaum.

Shaffer, J. F. (2016). Student performance in and perceptions of a high structure undergraduate human anatomy course. Anatomical Sciences Education, 9, 516-528.

Shanahan, C. (2012). Learning with text in science. In Jetton., T. \& Shanahan, C. (Eds.), Adolescent literacy in the academic disciplines. New York: Guilford.

Sikorski, J. F., Rich, K., Saville, B. K., Buskist, W., Drogan, O., \& Davis, S. F. (2002). Student use of introductory texts: Comparative survey findings from two universities. Teaching of Psychology, 29, 312-313.

Simpson, M. L., \& Nist, S. L. (1990). Textbook annotation-An effective and efficient study strategy for college-students. Journal of Reading, 34, $122-129$.

Snow, C. E. (2010). Academic language and the challenge of reading for learning about science. Science, 328, 450-452.

Solomon, P. R. (1979). 2-Point system-Method for encouraging students to read assigned material before class. Teaching of Psychology, 6, 77-80.

Theobald, R., \& Freeman, S. (2014). Is it the intervention or the students? Using linear regression to control for student characteristics in undergraduate STEM education research. CBE-Life Sciences Education, 13, 41-48.

van den Broek, P. (2010). Using texts in science education: Cognitive processes and knowledge representation. Science, 328, 453-456.

Vandsburger, E., \& Duncan-Daston, R. (2011). Evaluating the study guide as a tool for increasing students' accountability for reading the textbook. Journal of College Reading and Learning, 42, 6-23.

Van Meter, P. (2001). Drawing construction as a strategy for learning from text. British Journal of Educational Psychology, 93, 129-140.

Van Meter, P., Aleksic, M., Schwartz, A., \& Garner, J. (2006). Learner-generated drawing as a strategy for learning from content area text. Contemporary Educational Psychology, 31, 142-166.

Zapka, J. G., Bigelow, C., Hurley, T., Ford, L. D., Egelhofer, J., Cloud, W. M., \& Sachsse, E. (1996). Mammography use among sociodemographically diverse women: The accuracy of self-report. American Journal of Public Health, 86, 1016-1021. 